\title{
The impact of study abroad experiences on international students' employability: a preliminary study on Chinese engineering students in US
}

\author{
Qian Huang
}

Faculty of Education, The University of Hong Kong, China.

\begin{abstract}
This study aims to examine how study abroad experiences influence Chinese engineering students' employability. Employability in this study is defined as capabilities, processes and performances before job search, during job search and after job search. This study aims to explore how study abroad experiences contribute to engineering students' global competencies; how study abroad experiences influence engineering graduates' job search process; what the long-term impact of study abroad experience on engineering graduates' early careers are. This study adopts interpretative phenomenological approach via semi-structured interview. The preliminary findings include: firstly, study abroad experience is a premise for Chinese engineering students for being screened during job search both in China and abroad; secondly, study abroad allows students to discover their real interests which decided their career directions; thirdly, students kept learning and self-reflecting which contribute to their capabilities building; fourthly, study abroad trained engineering students with soft skills. Moreover, recommendation from professors and alumni facilitate the job search. Lastly, personal value and family reason influence graduates' career decisions in working in China or abroad. Conclusion was drawn that study abroad experiences have positive impact on engineering students' employability building, job search process and their early careers.
\end{abstract}

Keywords: Study abroad; global engineering competency; employability. 


\section{Introduction}

Aims of higher education have been changing for last centuries. The aim of the universities in medieval time was to nurture elite in the area of theology, law and medicine (Boden \& Nedeva, 2010). Since the 1960 s, to stimulate economy and decrease the inequality in education, the higher education has been massified to train young university student to be qualified workers in the job market (Teichler, 2009). Higher education institutions are expected to better prepare graduates being equipped with attributes required by job market (Barrie, 2006). Higher education institutions adopt many measures to enhance graduates' employability, for instance, through industry-led curriculum (Green et al., 2009), internship experience, study abroad, career counselling (Teichler, 2009). Social and economic conditions have also been changed. With globalization, higher education institutions design various global programs to enhance students global competency, for instance, English language immersion programs, internship abroad, study abroad (Yang, 2002).

Recent studies prove that study abroad experiences have a positive impact on graduates' employability. According to QS Global Employer Survey, 60\% employers believe the positive impact of study abroad (Coelen \& Gribble, 2020). In job search, study abroad experiences offer graduate a competitive advantage (Franklin, 2010). Study abroad experiences shown on the Curriculum Viate leaves the recruiters with the impression of adaptability, independence and cross-cultural awareness (Franklin, 2010). During interview session, study abroad experience provides students with evidence to say about their experiences and capabilities, especially their independence and resilience (Green et al., 2020). Study abroad experience influences graduates' career direction. Study experiences contribute greatly to their first career choice (Farrugia \& Sanger, 2017). Over 70\% alumni of study abroad programs do jobs with international dimensions, such as dealing with international clients, practicing international law (Franklin, 2010).

Furthermore, due to the changing job market condition caused by $4^{\text {th }}$ industrial revolution and new disruptive technologies for future engineers, the impact of study abroad experience on engineering students' employability are worth being examined. This study aims to explore following research questions: How do study abroad experiences contribute to engineering students' global competencies? How do study abroad experiences influence engineering graduates' job search process? What are the long-term impact of study abroad experience on engineering graduates' early careers. 


\section{Literature review}

\subsection{Global Engineering Competencies}

Future engineers should be named 'holistic engineers' because besides technical skills or hard skills, future engineers should have international awareness, equip with entrepreneurial spirit, the ability to innovate, the ability to work in a team cross disciplines, the ability to lead and manage projects in today's fast-changing world (Grasso \& Burkins, 2010). For wellrounded engineers in the 21 st century, they should be equipped with: 1) subject-related skills in math, science, etc; 2) engineering skills, system and integration; 3) soft skills in profession including the skills to communicate, to have team collaboration, to build contacts; and 4) business skills in cost accounting, scheduling and planning (Doyle, 2020). Global competency for engineers is defined as "knowledge, ability and predisposition to work effectively with people who define problems differently than they do" (Downey et al., 2006, p.110). Jeseik et al. (2014) measured global engineering comptency in three dimensions: technical coordination; engineering cultures; Ethics, standards and regulations. Chang et al. (2009) categorized three dimensions for competences of engineers: global competence; technical competences. Ball et al. (2012) used five types of global competencies: crosscultural communication, cross-cultural disposition, world knowledge, cross-cultural teams and engineering-specific cross-cultural competences. Mohtar and Dare (2012) measured global competency for engineering students in three dimensions: global technical, global professional and global sociocultural. Chan et al. (2017) stressed the importance of soft skills for engineering students, sometimes called generic skills or transferrable skills, refer to competencies and skills that beyond the discipline and can be transferred across different contexts.

\subsection{Graduate Employability}

In recent decade, academia keeps discussing the definition of graduate employability. Tomlinson (2017a) proposes that the graduate employability is conceptualized by human skills, social, cultural, identity and psychological capitals. There are five types of capital contributing to graduate's employability: 1) human skills capital: hard skills, soft skills and career building skills; 2) social capital: social network and contacts; 3) cultural capital: cultural knowledge \& behaviour, as well as symbolic value; 4) identity capital: graduate identity to be employed; 5) psychological capital: resilience, self-efficacy and adaptability. Cashian (2017) proposes social structure of employability model. In this model, employability is affected by three phases: pre-university, university and post-university. Student's background and family bonds are the factors at the pre-university levels. Before entering into university, students gained their connections, basic skills and attributes from family, schools, peers and communities. In university, students further gain knowledge and skills from degree subject learning, integration activities and community activities. In post- 
university stage, students get on-job-training and other workplace training. Therefore, the employability model is through lifespan with interaction in social world. Tomlinson (2017b) categorize graduate employability at three levels: micro level, meso level and macro level The micro level refers to student's individual skills and attributes and also the cultural and social capitals of their own; the meso level means that students' skills can be trained through institutional level, for instance, activities in university or training at work place; macro level means that employability is influenced by environment, for instance, the social and cultural surrounding in a bigger context. Holmes (2013) discusses the three types of employability: 1) possessional dimension: the skills \& attributes students own; 2) positional dimension: student-centred way to position themselves to actively train their skills and being prepared to work transition; 3) processual dimension: work transition is a process and many factors involved. Higher education is only a stage and students' social capitals and biographical factors have impact (Holmes, 2013).

\section{Research Methodology}

This study adopts a qualitative method in an interpretive paradigm which allows the researcher to collect data from listening to participants' voices and perspectives (Mackenzie \& Knipe, 2006). Phenomenological perspective is used to collect data via semi-structured interview. Phenomenology examines the lived individual experience of every participant. The experience is direct and subjective from participants. The researcher should "describe, understand, interpret and explain these experience" (Cohen et al., 2018, p.300). 10 participants were interviewed by researcher in this preliminary study as shown in Table 1. The participants were selected through purposive sampling. They were enrolled by top engineering research universities in China and joined study abroad programs, for instance, dual bachelor degrees program, combined bachelor and master degrees program. All of them studied engineering program abroad over one year. They are now in their early career either working in China or abroad. 
Table 1. Interviewees' Information.

\begin{tabular}{cccc}
\hline Name & Current Position & Education Background & $\begin{array}{c}\text { Work } \\
\text { Location }\end{array}$ \\
\hline Steve & Algorithm Engineer & Bachelor in China, Master + PhD in US & China \\
Lee & Software Engineer & Bachelor in China, Two Master in US & US \\
Tom & Fintech Engineer & Bachelor in China, Master in US & China \\
Shaun & AR/VR Engineer & Bachelor in China, Master in US & US \\
Alice & Supplier Engineer & Dual Bachelor in US, Master in USA & US \\
John & Process Engineer & Bachelor in China, Master in USA & China \\
Alex & Research Engineer & Bachelor in China, Master + PhD in US & US \\
Martin & Research Engineer & Bachelor in China, Master + PhD in US & US \\
Ruth & Software Engineer & Dual Bachelor in US, Master in US & US \\
Bill & Design Engineer & Bachelor in China, Master in US & China \\
\hline
\end{tabular}

Each interview was around 60 minutes by appointment. The interview was conducted via video communication on Zoom. The ethics issue and the video recording were read to the interviewees before the research interview questions being asked. The interview language is in Chinese which is the mother tongue of the researcher and all the interviewees. The audio of the interview was recorded and transcribed. The researcher examined the accuracy of the transcripts. The revised transcript was sent to each participant for re-examining its accuracy and the reliability.

\section{Preliminary findings}

Upon conducting in-depth interview with 10 participants in a semi-structured approach, here are preliminary findings: Firstly, based on the interview, the hard subjected-related skills are the core for engineering graduates' employability.

Bill: For engineering students, hard skills are the premise and the core. During the job interview, all the rounds of tests, including written, phone and on-site, are all about applying the subject-related knowledge to solve problems. In the onsite interviews, the managers or technical persons provided the engineer graduate with a real-world problem to solve.

Secondly, study abroad experiences not only provide engineering graduates with degree learning and the advanced research in lab, but also provide engineering students with the 
training for soft skills. The soft skills gained in their study are very helpful in their early career. Like what Ruth said, the soft skills become her strengths in her current position.

Shaun: During lab research, we need to collaborate with members from other labs, other universities and industry people. We learnt the proper way to connect with people from different cultural backgrounds.

Ruth: The most impressive course I took is Entrepreneurship I and II. The teacher owned a company before. So, he was very experienced. He showed us how to present and how to do proper gestures during presentation. He even invited industry people to serve as judges during our group presentation. I keep using the presentation skills he taught in my career. It is my strengths among colleagues in China.

Thirdly, during study abroad, students kept learning and self-reflecting so that they built capabilities, especially the intercultural communication skills, adaptability, upon graduation gradually.

Tom: In the $1^{\text {st }}$ semester, I spent every day learning and living with Chinese students. At the beginning of the $2^{\text {nd }}$ semester, I suddenly realized that I should meet and have local friends. So I thought an idea to go to church, not for the religion but for knowing local people and new friends. I happened to know a very friendly couple at their 70s. They invited international students to their home weekly. I had the opportunity to communicate among diverse groups.

Fourthly, study abroad allows students to discover their real interests and further decided their career directions. The wider range of course selection and curriculum with more flexibility in host universities provided them with more opportunities in selecting courses they like or they are curious about, which helped them further decide their career direction.

Steve: Study abroad experiences have a huge impact on my career direction. Because I studied mechanical engineering as my major in the first three years in China as my bachelor and then I was exchanged to USA for one year at my senior year. I was allowed to select more courses and then discover my real interest which lies in robotics. So I started to study robotics as my master degree and then further applied for PhD. The major studied abroad is the one I like and I decided to do it as my career.

Moreover, during study abroad, the host universities have many associations or services for career guidance for all students. For instance, the Career Fair each semester, the CV revising services, counselling services, career seminars by amateurs, etc. Professors and senior students in the same lab recommended them so that their CVs can be selected out more easily 
during screening, especially the top hi-tech companies. It is social capital the student accumulated.

Alice: The most difficult part is that your CV should be selected out among the huge amounts of CVs by HRs of top tech companies. The senior students who worked in the same lab recommended me so that my $C V$ was selected out and got the chance to be phone-interviewed for two rounds and onsite-interviewed for five rounds.

In addition, the bigger economic and political context do influence international students' career, especially during this pandemic time, as well as the changing visa policy based on the changing bilateral diplomatic relations.

Martin: I plan to change to other companies. However, I find it quite difficult to find jobs in pandemic times. Also, fewer companies are willing to offer H1B visa to international students due to current visa policy. Therefore, I feel lucky to have my current job in this pandemic time. I really hope that the new President will change the situation, and Sino-US relations as well.

Last but not least, some graduates returned to China to work because they noticed the promising opportunities for them that they can contribute what they learned in frontier tech to their motherland. Some graduates are staying abroad. They like the company culture, for instance the work and life balance, the mentor system for helping them personal growth. Some graduates are hesitated about returning or not. Because their parents prefer them returning to China, especially during the pandemic time. Therefore, personal values and external factors influence graduates' career decisions.

\section{Concluding Remarks}

In connecting engineering students' study abroad experiences and employability, participants express their great improvement in their soft skills including English proficiency in oral communication and academic writing, intercultural communication skills, presentation skills, adaptability in new environment and in diverse group. Participants agree that the most fundamental and vital factor for engineering students in job search is the subject-related hard skills and problem-solving skills. The soft skills trained during their study abroad contribute to their success in gaining the employment and more importantly, in maintaining and developing their early career in managing projects, collaborating in a team and further leading a diverse group. The study will be continued to interview more participants and more findings will be consolidated. The study will also shed lights on the reform of engineering education on how to embed soft skills training into current engineering curriculum at home, after all, not everyone can afford and has the ability to study abroad. 


\section{References}

Ball, A.G., Zaugg, H., Davies, R., L. Tateishi, I., Parkinson, R.A., Jensen C.G.,Magleby, S. P. (2012). Identification and Validation of a Set of Global Competencies for Engineering Students. International Journal of Engineering Education. 28. 156-168.

Barrie, S. C. (2006). Understanding what we mean by the generic attributes of graduates. Higher Education, 51(2), 215-241.

Boden, R. \& Nedeva M. (2010). Employing discourse: universities and graduate 'employability', Journal of Education Policy, 25(1), 37-54

Cashian, P. (2017). Developing a more coherent and robust basis for employability research: a critical realist perspective, in Tomlinson. M, Holmes, L (2017). Graduate employability in context, London: Macmillan Publishers

Chan, C.K.Y, Wong, G.C.K, Law, A.K.H, Zhang, T, \& Au, F.T.K. (2017). Evidence-based conclusions concerning practice, curriculum design and curriculum reform in a civil engineering capstone design course in Hong Kong. Innovations in Education and Teaching International, 54(3), 260-274.

Chang, Y. Atkinson, D. and Hirleman, H.D. (2009). International research and engineering education: Impacts and best practices. Online Journal of Global Engineering Education, 4(2)

Coelen, R. \& Gribble, C. (2020), Internationalization and Employability in Higher Education, New York: Routledge

Downey, G.L., Lucena, J.C., Moskal, B.M., Parkhurst, R., Bigley, T., Hays, C. Jesiek, B.K, Lehr, J.L. and Nichols - Belo, A. (2006). The globally competent engineer: Working effectively with people who define problems differently. Journal of Engineering Education (Washington, D.C.), 95(2), 107-122.

Doyle, A. (2020). Important Job Skills for Engineers, retrieved from https://www.thebalancecareers.com/list-of-engineering-skills-2063751

Farrugia, C., \& Sanger, J. (2017). Gaining an Employer Edge: The Impact of Study Abroad on 21st Century Skills \& Career Prospects. New York, NY: Institute of International Education.

Franklin, K. (2010). Long-term career impact and professional applicability of the study abroad experience, Frontiers: The Interdisciplinary Journal of Study Abroad, 19

Grasso, D. \& Burkins, M.B. (2010). Beyond technology: the holistic advantage, in Grasso, Domenico, \& Burkins, Melody Brown. (2010). Holistic Engineering Education (1. Aufl. ed.). New York, NY: Springer-Verlag.

Green, W., Hammer, S., \& Star, C. (2009). Facing up to the challenge: Why is it so hard to develop graduate attributes? Higher Education Research \& Development, 28(1), 17-29.

Holmes, L. (2013). Competing perspectives on graduate employability: Possession, position or process? Studies in Higher Education (Dorchester-on-Thames), 38(4), 538-554.

Jesiek, B.K., Zhu, Q., Woo, S.E., Thompson, J., and Mazzurco, A. (2014). Global engineering competency in context: Situations and behaviours. Online Journal of Global Engineering Education, 8(1):1 
Mackenzie, N., \& Knipe, S. (2006). Research dilemmas: paradigms, methods and methodology. Issues in Educational Research. 16(2)

Mohtar, R.H. and Dare, A.E. (2012). Global design team: A global service-learning experience, International Journal of engineering education, 28(1), 169-182

Teichler, U. (2009). Higher Education and the World of Work. Conceptual Frameworks, Comparative Perspectives, Empirical Findings. The Netherlands: Sense Publishers

Tomlinson, M. (2017a). Forms of graduate capital and their relationship to graduate employability. Education and Training, 59(4)

Tomlinson, M. (2017b). Introduction: graduate employability in context: charting a complex, contested and multi-faceted policy and research field, in Tomlinson, M. \& Holmes, L. (2017), Graduate employability in context, London: Palgrave Macmillan.

Yang, R. (2002). The Third Delight: Internationalization of Higher Education in China (East Asia (New York, N.Y.). New York: Routledge. 